\title{
Intraocular Retinal Transplantation: A Review
}

\author{
R.M. Hammer and U. Yinon \\ Physiological Laboratory, Maurice \& Gabriela Goldschleger Eye Research Institute \\ Tel Aviv University, Sackler Faculty of Medicine, Chaim Sheba Medical Center, \\ Tel Hashomer 52621, Israel
}

\begin{abstract}
SUMMARY
This review covers intraocular transplantation of retinal tissue. This has importance both for theoretical understanding of retinal and neural development and for possible future clinical application.

Transplantation sites have ranged from the anterior chamber through the retina to the subretinal space. Transplanted tissue has ranged from whole retina to specific retinal layers or specific types of retinal cells. Both within-species and inter-species transplants have been performed, and donor age has ranged from embryonic to adult. The ability of transplanted tissue to be accepted and to differentiate in host eyes has been studied. The conditions under which successful transplants are obtained, host-graft interactions, and transplantation methodologies have been explored. Morphological, and to a small extent, also functional characteristics of the transplants have been studied.
\end{abstract}

Reprint address:

U. Yinon

Physiological Laboratory

Goldschleger Eye Research Institute

Sheba Medical Center

Tel Hashomer 52621

Israel

\section{KEY WORDS}

Retinal transplant, retinal graft, retinal implant, eye, pigment epithelium, rods, photoreceptors

\section{INTRODUCTION}

Studying retinal transplants is a way of obtaining insights into the development of retinal tissue and factors which influence this, the formation of neural connections, and interactions between transplanted and surrounding tissue. Additionally, there are many eye diseases which due to their effects on the retina cause severe visual loss. It is important to begin to preliminarily explore the possibility that transplantation techniques may be a means of replacing irreversibly damaged retinal tissue.

Studies of the development of retinal tissue when transplanted into host brains have been reported for some time $/ 38,40-43 /$.

Apart from one pioneering study $/ 46 /$, intraocular retinal transplants have been carried out only relatively recently. The sparse literature regarding retinal transplants up to mid-1986 has been reviewed /60/ and integrated into a review of retinal transplants into the brain, along with the use of peripheral nerve grafts 
as bridges for the growth of retinal ganglion cells. A further review of retinal transplantation /11/ has also recently come to our attention.

The present review emphasizes recent developments in the transplantation of retinal tissue into host eyes.

\section{TRANSPLANTS OF WHOLE RETINA}

\section{Transplants into the Anterior Chamber}

Del Cerro et al. grafted retinas from Long-Evans rat embryos aged 13 to 16 postconceptual days (E13-E16) $/ 14,15$ / and 2 days post-natal (P2) $/ 15 /$, to the anterior chambers of adults, both of the same species, and also of other species, namely Lewis $/ 14,15 /$ and Fischer /14/. The transplanted neural retina and the retinal pigment epithelium (RPE) grew at a roughly linear rate until one month after transplantation, after which its size and appearance remained unchanged. Iridal vessels entered the implants and formed branches with them. The capillaries within the implant formed tufts around the trunks of origin, in contrast to the vascular network found in normal, rat retinas. Survival times (time from transplant till sacrifice) allowed in the study ranged from 0 to 90 days, with long-term survival rate for transplants larger than $1 \mathrm{~mm}$ ranging from $25 \%$ to $80 \%$.

Fifteen days proved adequate for the differentiation of a rudimentary layered structure $/ 14,15 /$. This included patches of outer (ONL) and inner (INL) nuclear layers (the INL sometimes forming a distinct layer), as well as definite inner limiting membranes (ILM) with baskets of Muller cell processes and outer limiting membranes (OLM) and outer plexiform layers (OPL). The plexiform layers contained numerous synaptic endings and both ribbon and conventional synaptic contacts $/ 14,15 /$. (A ribbon synapse is characterized by a dense ribbon or bar seen in the electron micrograph of the presynaptic cytoplasm and always has multiple post-synaptic elements /23/. Conventional synaptic contacts in the retina are similar to those found throughout the vertebrate nervous system $/ 23 /$. Both types of synapses would be expected to be found if the transplant resembles normal adult retinal tissue.) Photoreceptor outer segments, which were all stunted $/ 14,15 /$, were only observed to develop when the pigment epithelium was present near, though not necessarily in contact with, the rod cells $/ 14 /$. Rod cells were closely packed, and in some cases formed rosettes within the thickness of the ONL and INL $/ 14,15 /$. Ganglion cells were present in transplants from embryonic $/ 14,15 /$, but not from post-natal /15/ donors, and were few in number.

Within-species transplants were very well tolerated by the host, even 3 months post-transplantation $/ 14,15 /$. Lewis strain hosts usually did not show inflammation /12,13/ while Fischer strain hosts showed an intense reaction /14/. This began in the form of vascular congestion of the iris, which could progress to general hyperemia of the conjunctiva, with clouding of the media. In the two worst cases, such alterations as anterior chamber hemorrhages, cataractous changes, along with vascularization and opacification of the cornea occurred. In these severe cases, the transplants were surrounded and infiltrated by macrophages, which were also plentiful in the host retina and were a major component of a granulomatous tissue found throughout the vitreal cavity.

Ninomiya /45/ transplanted retina from E13-E20 Fischer rats to the anterior chambers of adults, with survival times of 2-37 weeks. The transplanted tissue was seen as an irregular translucent whitish mass into which small blood vessels entered. Microscopically, tubular structures of varying sizes and some rosettelike structures were seen. Survival rate was $22 \%$, but if a co-transplant of tectal tissue was made, then it was $74 \%$. The retina-tectum double grafts fused about 2 weeks after transplantation.

\section{Transplants to the Host Retina}

Rat to rat transplants. Del Cerro et al. /12/ performed transplants from both embryonic and P1-P2 postnatal outbred Long-Evans rats into the retinas of adult male outbred Long-Evans rats and albino Lewis strain rats. The host retinas were either damaged prior to transplantation by light or by kainic acid or were normal. The transplant was either in the form of strips of retina or of a cell suspension. Survival times of up to 90 days were allowed. A mass of retinal tissue was found to develop on the host retina, and the nuclear and plexiform layers differentiated and were populated by the expected neuronal and glial types. Differentiation included the appearance of numerous rod cells, often forming rosettes, and a few cones. The 
lumina of these rosettes were limited by an OLM and were filled by cilia-bearing inner segments and contorted outer segments. They also contained some macrophages loaded with cytoplasmic debris. The layers of the transplant came to blend with those of the host as they grew and became progressively vascularized. Synapses, both of the conventional and ribbon types, were found within the plexiform layer of the transplant $/ 12 /$. In these types of transplant, and with survival times up to 120 days, no evidence of immune mediated rejection was found $/ 13 /$.

In a similar study $/ 20 /$, dissociated retinal cell suspension, in some cases prestained with either Fast blue or Fluoro-gold, was obtained from P1-P2 LongEvans and Lewis pups. The cells were injected into the retinas of Long-Evans, Lewis and Fisher hosts (some phototoxically damaged). With survival times of 10,30 , and 100 days, the transplants showed excellent integration with the host tissue, without any glial barrier. In those cases which were not prelabelled, it was difficult to define precisely the distribution of the transplant in the normal host retinas. Precise transplant survival data were not given, but it was mentioned that in a few cases, viable grafts failed to occur $/ 20 /$.

Further details regarding the results of transplantation of retinal cell suspensions to light-damaged host retinas have been reported for adult Fisher rat hosts with donors of the same species $/ 17,19 /$. The photodamage had been achieved by 4 weeks of 12 hours per day of exposure to an illuminance of 3500 lux from fluorescent lamps. Transplants were from P2 donors, and were allowed to grow 3-100 days. They were found to grow well, although the laminar organization was less regular than in other transplantation methods $/ 17,19 /$. Density of rod cell nuclei in the transplant was high (145 nuclei per $250 \mu \mathrm{m}$ of retina), as compared to almost zero in light-damaged retinas without transplants (2.8 nuclei per $250 \mu \mathrm{m}$ of retina), but it was approximately one-third of that found in the corresponding area of normal control retinas (415 nuclei per $250 \mu \mathrm{m}$ of retina) $/ 17 /$. Rod cells were usually grouped in rosettes $/ 17,19 /$. Their inner segments developed consistently, while their outer segments tended to be defective, containing collections of irregular cisternae. Many synapses, both of the conventional and ribbon type, occurred within patches of plexiform layer around the grafts.
Transplants could be found in approximately twothirds of transplanted eyes.

Similar results were also obtained when transplants to photodamaged albino Lewis rats were performed, with donor material from P0 to P2 Lewis or LongEvans rats $/ 18 /$.

Turner and Blair obtained donor retinal tissue from newborn rat pups $/ 56 /$. The retinas of the adult Sprague-Dawley hosts were lesioned by means of a razor blade that was passed through the layers of the eye until the vitreous was exposed, the incision being subsequently sutured closed. Donor retinas were cut into small pieces and injected into a host lesion site. The lesion either was newly prepared or 5 weeks old. Within 1 week post-transplantation, a distinct ganglion cell layer two or three cells thick was present, but without an optic fiber layer. There was a small inner plexiform layer (IPL) between the ganglion cell layer and the neuroblastic layer. At four weeks, an ILM and a continuous optic fiber layer were still absent. In some cases, however, fascicles of fibers ran from the graft ganglion cell layer and joined with and coursed for some distance along the host ILM/optic fiber layer. The neuroblastic layer had developed into an INL and an ONL separated by an OPL. Both ribbon and conventional synapses were present. Photoreceptor cell bodies and inner segments, but not outer segments, were found. The photoreceptors on occasion collected to form rosettes, with the cell bodies facing an inner luminal surface filled with microvilli. Merging of the plexiform layers of the graft and the host was observed. A clear distinction could be made between the host and graft tissue, the latter being located mostly within the cut edges of the lesion in the host retina. The transplants were successful for both fresh and 5-week-old lesion sites /56/ and also for 8-weekold lesion sites $/ 59 /$. This last point, regarding lack of influence of lesion age on the success of the transplant, was also confirmed in a further study /4/.

Retinal transplants were performed by the same method, both from P1 pups and from E15 SpragueDawley embryos, into lesioned retinas of young adults of the same species $/ 2,61 /$. Six to 7 weeks posttransplant, the P1 transplants had fewer laminae (only ganglion cell layer, IPL, INL and ONL) than the E15 transplants (OPL and OLM also present). The P1 transplants also integrated more poorly within the host retina under fresh lesion conditions, but equally well in 
older lesions. For both donor ages, a continuous optic fiber layer and the ILM were again absent $/ 2,61 /$. Glial cells from within embryonic grafts developed normally, while host glial cells also migrated into the grafts $/ 49,61 /$. Graft filling and viability did not differ between newborn or embryonic donors /2,61/.

Retinal graft from E15 donors to a fresh lesion site also reduces the degeneration in the host retina in the region surrounding the lesion, compared to that which occurs with the lesion alone $/ 32 /$. This effect is not specific for retinal grafts; similar results are obtained if sciatic nerve pieces are implanted, but not with implants of sheath tissue or tendon $/ 57,58 /$.

An earlier study /4/ from the same laboratory involved using retinal donor material from $\mathrm{P} 10$ and P1 pups and E14-E20 embryos. The grafts were histologically examined when they reached the equivalent of age P28. They found that 10-day-old donor material resulted in a lower "evaluation index" (a quantitative measure of graft survival, lamination, integration with host retina, absence of non-neuronal barriers, and lesion filling and repair by the graft tissue) than that from 1-day-old donors. No significant difference in the "evaluation index" was found, however, between transplants from P1 pups and the embryos. The transplants from P10 donors had essentially no ganglion cell layer or IPL present. The cells from the INL were relatively few in number and quite disorganized. Massive fiber outputs which did leave younger grafts were absent from the P10 graft tissue. Photoreceptor cells dominated the cytoarchitecture of these grafts in the absence of normal populations of other cell types. The average survival rate was over $90 \% / 4 /$. As donor age increased from P2 to P21, the success of the transplant progressively declined. For P21 donors the transplant completely degenerated within 2 days, with no viable grafted tissue found in the lesion site /2,61/. Daily Cyclosporin A injections, however, allowed healthy retinal donor cells from 21-day-old donors to survive for at least 6 days $/ 3 /$. If given only for the first 24 hours, only a remnant of the graft remained at 6 days, and it was infiltrated by connective tissue and some macrophages $/ 3 /$.

It is interesting to note that integration even of donor retina frozen for several months to the temperature of liquid nitrogen is possible, although over a narrower range of donor ages $/ 47 /$. The optimal donor age for transplants of strips of retina into lesioned host retinas is approximately E16. Donor age in excess of E19 leads to poorer success and differentiation, while E13 donor tissue rarely survives. Retinal tissue cryopreserved for 8 months survives and differentiates just as well as tissue cryopreserved for 4 months $/ 47 /$.

Xenografts to rat hosts. Retinas transplanted from mouse embryos into retinal lesions of adult SpragueDawley rats required that the hosts be treated with daily Cyclosporin A $(10 \mathrm{mg} / \mathrm{kg})$ in order for the transplant to survive 30 days $/ 3,61 /$. At 8 to 9 days post-transplantation, the grafts were still mostly undifferentiated and consisted of a neuroepithelial layer. By 30 days, the ONL, INL, IPL and ganglion cell layers were all identifiable within the rosette structures of the graft $/ 3,61 /$.

In contrast to this result, strips of retina from newborn C57BL/6J mice transplanted into the posterior poles of Fisher 344 albino rats were still well accepted 17 days post-transplant without any immunosuppression $/ 8-10 /$. The transplants differentiated into ONL cells (with inner and outer segments attached to them), INL cells, and a plexiform layer. The reaction of the appearance of a few macrophages around the transplant was reported as being no worse than that found in corresponding intraspecies transplants /8-10/.

.Strips of retina from a P60 and a P90 Cebus Appella monkey fetus transplanted into the eyes of adult Fisher 344 albino rats to which Cyclosporin A was administered were still not rejected 33 days posttransplant $/ 16,31 /$. The graft differentiated into ONL cells with inner segments attached to them, INL cells, and a plexiform layer. It integrated well with the host retina and sometimes also expanded into the vitreal cavity $/ 16,31 /$.

Non-rat hosts. The rabbit and the mouse are among the few species other than rats to have been utilized as intraocular whole retina transplant recipients.

Retinas from E15 albino rabbits have been transplanted to surgically lesioned retinas of 4- to 6week-old albino rabbits /48/. At 4 weeks posttransplant, grafts of approximately $2 \mathrm{~mm}$ in diameter were found. Rosettes in the graft contained all retinal cell layers, with the exception of the ILM /48/. At 8 weeks post-transplant, the grafts appeared to be smaller and with fewer rosettes $/ 1 /$. Transplanted 
whole retina which included the RPE led to a higher success rate and usually larger graft sizes at 4 weeks post-transplant than whole retina without the RPE $/ 1 /$.

Normal retinas from $\mathrm{P} 0$ mice were transplanted into adult mice with inherited retinal degeneration ( $\mathrm{rd} / \mathrm{rd}$ ) /29/. Three days after the transplant, rosettes of grafted tissue showed photoreceptor differentiation. The survival rate for the transplants was high at 3 days post-transplant but dropped dramatically at 10-15 days, with a regressive change in the photoreceptors. Transplants from P0 (rd/rd) mice into normal mice, on the other hand, still had a good survival rate 10-15 days post-transplant, the grafts having numerous rosettes and some photoreceptors having well developed outer segments $/ 29 /$. By 30 days the survival rate was reduced, but photoreceptors were still the majority of surviving cells $/ 30 /$. The authors concluded that the retina or the intrinsic cellular defect itself may not be the only factors playing a role in this type of retinal degeneration $/ 29,30 /$.

\section{TRANSPLANTS OF SPECIFIC RETINAL COMPONENTS}

So far in this review, whole retinal transplants have been discussed. Transplants of retinal components alone will now be considered.

\section{Transplant of Separated Retinal Layers}

Retinas from P4 Fisher rat donors have been separated into an outer layer consisting mainly of neuroblasts and an inner layer consisting primarily of ganglion cells, displaced amacrine cells, and astroglial elements $/ 21,22,39 /$. Both layers of cells, when transplanted into both normal and light-damaged retinas of adult Fisher rats, successfully differentiated into photoreceptors, a plexiform layer, and a cell layer which was presumably the inner nuclear layer. Inner layer transplants survived better than outer layer transplants.

The intact photoreceptor matrix separated from the retinas of normal 7-day-old Sprague-Dawley rats has been transplanted to the subretinal space of photodamaged retinas of adult albino hosts of the same species /54/. Transplanted photoreceptors were found at survival times of 2, 4, and 6 weeks, with an overall success rate of $67 \%$. The transplant remained approximately constant in size with survival time, and consisted of columnar stacks of about 12 cell bodies, which is characteristic of the photoreceptor layer, as well as some rosette formations. The number and length of photoreceptor outer segments was reduced, however $/ 54 /$.

Photoreceptor layer transplants from adult human eyebank eyes to photodamaged adult host retinas were also successful, but only if the host rats were immunosuppressed /52/.

\section{Retinal Pigment Epithelium (RPE) Transplants}

The retinal layer which has most frequently been transplanted alone is the RPE. The earliest report of RPE transplant was from Gouras et al. They obtained human RPE cells from donors aged 65 to 85 years within 12 to 24 hours after death and cultured them in vivo $/ 27 /$. Cells from the primary culture were subcultured and radiolabelled. The subcultured cells were transplanted to an area of Bruch's membrane of owl monkeys which had been exposed and denuded of host RPE cells. Survival times ranged from 2 hours to 7 days. Transplanted cells had already attached to the denuded area of Bruch's membrane at 2 hours and continued to divide thereafter. Leukocytes were observed in the choriocapillaris and Bruch's membrane at times as early as 2 hours. Macrophages appeared in the choriocapillaris and Bruch's membrane beginning at 3 days and increasing in number up to 7 days (immunosuppression was not used).

Lopez et al. performed transplants of cultured rabbit RPE cells from adult albino and pigmented rabbits to the subretinal space of normal adult pigmented rabbits /36/. Within an hour, cells attached to Bruch's membrane, and at 24 hours (the longest posttransplant time reported), some cells were phagocytosing receptor outer membranes. The success rate for the most successful method attempted was approximately $25 \%$. The main problems encountered in their transplants were breaks in Bruch's membrane, unsuccessful denudation of the host pigment epithelium, and failure to inject a sufficient number of donor cells /36/. 
When this type of transplant was followed for 6 months in non-immunosuppressed rabbits, there were granulomatous reactions with damage to the choriocapillaris and overlying photoreceptors $/ 5 /$. Inflammatory cells traversed Bruch's membrane and entered the subretinal space. It was possible, however, to prevent these reactions, while also enabling transplanted RPE to survive the 6-month period by administering Cyclosporin /5/.

$\mathrm{Li}$ and Turner /34/ have transplanted cultured RPE cells from P6-P8 Long-Evans rat pups to SpragueDawley rat hosts of ages ranging from P10 to adult. Approach to the subretinal space was through the dorsal surface of the eye, without passing through the vitreous. Using survival times ranging from 2 hours to 3 months, the grafts were successful for all host ages attempted, with an overall success rate of $95 \%$. The photoreceptors underlying the grafts remained normal.

An additional study describes pigment epithelium taken from the peripheral retina of 12- to 20 -week-old Gottingen miniature pigs and transplanted to the subretinal space at the posterior pole of the same eye (autologous transplant) /33/. Cell attachment to Bruch's membrane was demonstrated 1 hour posttransplant. Efflux of cells to the vitreous and significant subretinal hemorrhage occurred in $40 \%$ of cases.

At least two laboratories have attempted to apply RPE transplantation to the prevention of the hereditary photoreceptor degeneration in the Royal College of Surgeons (RCS) rat, as will be discussed in the paragraphs which immediately follow. There is evidence that the gene for the retinal dystrophy in the RCS rat acts on the RPE cells /44/. Phagocytosis by RPE cells of photoreceptor outer segments, which is an important function of normal RPE cells, is deficient in the RCS rat $/ 6 /$. Photoreceptor outer segments differentiate and elongate in a normal fashion until age P18; by P22, degeneration of photoreceptor cell nuclei is well underway, and photoreceptor degeneration is almost complete by P60 /24/. The implication of the RPE in this process (and the possibility that this may be a model for certain human retinal degenerations) has spurred the following studies.

Lopez et al. transplanted freshly harvested dissociated RPE cells from pigmented normal rats (of unspecified age; presumably adults) to the subretinal space of congenic RCS rats of age P15-P22 /37/. As long as 4 months post-transplant, areas in which transplanted RPE cells were present also had photoreceptor cells. The more donor RPE cells present in a region, the thicker was the host's photoreceptor cell layer in that region. Transplanted pigment epithelial cells contained many more phagosomes than normal $/ 37 /$, while older cells /28/ had a higher content of older phagosomes than younger ones. Receptors survived even at a distance from transplants $/ 28 /$.

$\mathrm{Li}$ and Turner transplanted RPE cells from blackeyed Long-Evans P6-P8 rats to the subretinal space of P26 non-pigmented RCS hosts with a $100 \%$ success rate $/ 35 /$. When the hosts reached age 60 days, there was a retinal area of approximately $4.2 \mathrm{~mm}^{2}$ where degeneration of host photoreceptors was prevented. Distinct zones of photoreceptor outer and inner segments were found, and the OPL was not reduced in thickness compared to its thickness at P26. In P60 nongrafted controls, however, the receptor outer segment membranes formed only a debris zone, while the inner segments had disappeared. The OPL was one-third of the thickness it had at 26 days /35/. Sheedlo et al. further found that the thickness of the ONL varied little in the region beneath a graft, even though the distribution of donor cells within the region of the transplant was typically random /50/. Starting at the transition zone between the graft and the host RPE, the ONL began to decrease in thickness. The distribution in retinal regions where photoreceptor degeneration was prevented of the membrane protein $\mathrm{Na}^{+}, \mathrm{K}^{+}$-ATPase and of the photoprotein Opsin was not different from that found in normal control LongEvans rats. Both those transplanted RPE cells attached to Bruch's membrane and those on the apical surface of other RPE cells appeared to be able to ingest shed rod outer segments and membrane debris /50/. RPE transplants are able to prevent photoreceptor degeneration only if performed prior to the host age of approximately 30 days /51/. For transplants performed at P39, there was no significant photoreceptor cell rescue 3 months after grafting /51/.

While transplant of RPE alone does not effect photoreceptor rescue for RCS rat hosts older than P39 /51/, transplant of RPE together with dissociated photoreceptors to the subretinal space of 4- to 6month-old hosts has been attempted $/ 25,26 /$. Survival time of only 24 hours was reported, and photoreceptors were found in the subretinal space $/ 25,26 /$. 
While RPE transplants have been found to prevent photoreceptor degeneration in RCS rats, a third laboratory has found that surgical manipulation alone in P25 and P36 RCS rats, including injection of saline or implantation of a gelatin carrier without transplanted cells, is sufficient to prevent photoreceptor degeneration in the region of the surgery just as effectively $/ 55 /$. Survival times of up to 2 months postsurgically were utilized $/ 55 /$. The only one of the above-cited studies of RPE transplantation to RCS rats which included a sham control group /51/ (vehicle injected at $\mathbf{1 7}$ days) found only a partial and short-lived photoreceptor cell rescue. At age 2 months, the ONL was much thinner than with RPE transplant, and in a much smaller area, while at 3 months the rescue effect was no longer seen.

\section{TRANSPLANT FUNCTION}

In addition to observing the structural characteristics of transplanted retinal tissue, it is important to assess the extent to which the transplant functions like normal retina, and whether it successfully conveys visual information to higher centers. The sparse information on this subject which is available at the present early stage in the history and development of intraocular retinal transplantation is presented in this concluding section.

One study reports on the 2-deoxyglucose uptake in photoreceptors transplanted from P8 donors to adults with light-damaged retinas (they do not mention which animal) $/ 53 /$. The uptake patterns in transplanted photoreceptor regions and underlying host INL, both under dark conditions and under $10 \mathrm{~Hz}$ flicker stimulus, were similar to that of normal retina.

Another study has been carried out on transplantation of retina from pigmented Westenberg LongEvans rats to the anterior chamber of albino rats of the same species $/ 7 /$. The response of the host retina to light, as measured by the electroretinogram (ERG), had been eliminated by poisoning with 6-hydroxydopamine. The ERG was detected in rats which received retinal transplants, while it was absent in those which received no transplant or a sham transplant of medium only.

\section{ACKNOWLEDGEMENT}

R.M. Hammer is grateful to the University of New South Wales, Australia, for granting him permission to perform work towards his $\mathrm{MSc}(\mathrm{Optom})$ degree at the Physiological Laboratory, Goldschleger Eye Research Institute, Tel Aviv University, Israel, where this work was carried out.

\section{REFERENCES}

1. Aramant R, Seiler M, Bergstrom A, Adolph AR. Cografts of retina and retinal pigment epithelium to adult rabbit retina. Soc Neurosci Abstr 1989; 15:1367.

2. Aramant R, Seiler M, Turner JE. Donor age influences on the success of retinal grafts to adult rat retina. Invest Ophthalmol Vis Sci 1988; 29:498-503.

3. Aramant $R$, Turner JE. Cross-species grafting of embryonic mouse and grafting of older postnatal rat retinas into the lesioned adult rat eye: the importance of cyclosporin A for survival. Dev Brain Res 1988; 41:303-307.

4. Blair JR, Turner JE. Optimum conditions for successful transplantation of immature rat retina to the lesioned adult retina. Dev Brain Res 1987; 36:257-270.

5. Brittis M, Lopez R, Kjeldbye H, Sullivan B, Gouras P. Long-term pigment epithelial transplantation in the rabbit with immunosuppression. ARVO Abstracts, Invest Ophthalmol Vis Sci 1989; 30 (Suppl):209.

6. Bok D, Hall MO. The role of the pigment epithelium in the etiology of inherited retinal dystrophy in the rat. J Cell Biol 1971; 49:664-682.

7. Collier RJ, del Cerro M, Yeh HH, del Cerro C, Trojanczyk LA, Westenberg IA. Electroretinographic assessment of intraocular retinal transplant. ARVO Abstracts, Invest Ophthalmol Vis Sci 1989; 30 (Suppl): 349.

8. del Cerro C, Jiang LQ, del Cerro M. Interspecies retinal transplantation. Soc Neurosci Abstr 1988; 14:1276.

9. del Cerro C, Jiang LQ, Gallousis SM, del Cerro M. Interspecies retinal transplantation in rodents. IIIrd International Symposium on Neural Transplantation, Restor Neurol Neurosci 1989; Supp1:29.

10. del Cerro C, Gallousis SM, Lazar E, del Cerro M. Transplantation of immature mouse retina into adult rat eyes. Soc Neurosci Abstr 1989; 15:1367.

11. del Cerro M. Retinal transplants, Progress in retinal research. Submitted for publication.

12. del Cerro M, Gash DM, Notter MF, Wiegand SJ, Jiang LQ, del Cerro C. Transplants of retinal cells into the normal and damaged retina of genetically dissimilar adult hosts. Soc Neurosci Abstr 1986; 12:561. 
13. del Cerro M, Gash DM, Notter MFD, Rao GN, Wiegand SJ, Jiang LQ, del Cerro C. Transplanting strips of immature retinal tissue and suspensions of dissociated retinal cells into normal and extensively damaged eyes. Ann NY Acad Sci 1987; 495:692-695.

14. del Cerro M, Gash DM, Rao GN, Notter MF, Wiegand SJ, Gupta M. Intraocular retinal transplants. Invest Ophthalmol Vis Sci 1985; 26:1182-1185.

15. del Cerro M, Gash DM, Rao GN, Notter MF, Wiegand SJ, Sathi S, del Cerro C. Retinal transplants into the anterior chamber of the rat eye. Neuroscience 1987; 21:707-723.

16. del Cerro M, Kordower JH, del Cerro C. Fetal retina transplanted into adult rat eyes. IIIrd International Symposium on Neural Transplantation, Restor Neurol Neurosci 1989; Suppl:29-30.

17. del Cerro M, Notter MFD, del Cerro C, Wiegand SJ, Grover DA, Lazar E. Intraretinal transplantation for rod-cell replacement in light-damaged retinas. J Neuro Transplant 1989; 1:1-10.

18. del Cerro M, Notter MF, Grover DA, Gash DM, Jiang LQ, del Cerro C. Retinal transplants into adult eyes affected by phototoxic retinopathy. Prog Brain Res 1988; 78: $125-130$.

19. del Cerro M, Notter MF, Grover DA, Olchowka J, Jiang LQ, Wiegand SJ, Lazar E, del Cerro C. Retinal transplants for cell replacement in phototoxic retinal degeneration. In MM LaVail, RE Anderson, JG Hollyfield (Eds.), Inherited and environmentally induced retinal degenerations. New York: Alan R Liss, 1989, pp. 673-686.

20. del Cerro M, Notter MFD, Wiegand SJ, Jiang LQ, del Cerro C. Intraretinal transplantation of fluorescently labeled retinal cell suspensions. Neurosci Lett 1988; 92:21-26

21. del Cerro M, Yeh HH. Transplantation of enriched cell populations derived from immature rat retina. Soc Neurosc Abstr 1988; 14:1275.

22. del Cerro M, Yeh HH. Selective transplantation of enriched cell populations derived from immature rat retina. ARVO Abstracts, Invest Ophthalmol Vis Sci 1989; 30 (Suppl):208

23. Dowling JE. Organization of vertebrate retinas. Invest Ophthalmol 1970; 9:655-680.

24. Dowling JE, Sidman RL. Inherited retinal dystrophy in the rat. J Cell Biol 1962; 14:73-109.

25. Gelanze M, Du J, Lopez R, Gouras P. Survival of photoreceptors transplanted to the subretinal space of adult RCS rats. ARVO Abstracts, Invest Ophthalmol Vis Sci 1989; 30 (Suppl):208.

26. Gouras P, Du J, Gelanze M, Lopez R, Kjeldbye H. Transplantation of rods to rodless rat retina. Soc Neurosci Abstr 1989; 15:10.

27. Gouras P, Flood MT, Kjeldbye H, Bilck MK, Eggers $H$. Transplantation of cultured human retinal epithelium to Bruch's membrane of owl monkey's eye. Curr Eye Res $1985 ; 4:$ 253-265.
28. Gouras P, Lopez R, Kjeldbye H, Sullivan B, Brittis M. Hyperphagocytosis of outer segments by normal RPE transplanted to the subretinal space of RCS rats. ARVO Abstracts, Invest Ophthalmol Vis Sci 1989; 30 (Suppl):209.

29. Jiang LQ, del Cerro M. Retinal transplantation as a tool for the study of retinal degeneration. IIIrd International Symposium on Neural Transplantation. Restor Neurol Neurosci 1989; Suppl:29.

30. Jiang LQ, del Cerro $M$. Retinal transplantation as a tool for the study of retinal degeneration. Soc Neurosci Abstr 1989; 15:1367.

31. Kordower J, del Cerro M. Fetal monkey retina transplanted into adult rat eyes. ARVO Abstracts, Invest Ophthalmol Vis Sci 1989; 30 (Suppl):208.

32. Laedtke TW, Turner JE. Embryonic retinal grafts have a beneficial effect on the damaged host retina. Brain Res 1989; 500:61-66.

33. Lane C, Boulton M, Bridgman A, Marshall J. Transplantation of retinal pigment epithelmium in the miniature pig. ARVO Abstracts, Invest Ophthalmol Vis Sci 1988; 29 (Suppl): 405.

34. Li L, Turner JE. Transplantation of retinal pigment epithelial cells to immature and adult rat hosts: shortand long-term survival characteristics. Exp Eye Res 1988; 47:771-785.

35. Li L, Turner JE. Inherited retinal dystrophy in the RCS rat: prevention of photoreceptor degeneration by pigment epithelial cell transplantation. Exp Eye Res 1988; 47:911-917.

36. Lopez R, Gouras P, Brittis $M$, Kjeldbye $H$. Transplantation of cultured rabbit retinal epithelium to rabbit retina using a closed-eye method. Invest Ophthal Vis Sci 1987; 28:1131-1137.

37. Lopez P, Gouras P, Kjeldbye H, Sullivan B, Reppucci V, Brittis M, Wapner F, Goluboff E. Transplanted retinal pigment epithelium modifies the retinal degeneration in the RCS rat. Invest Ophthal Vis Sci 1989; 30:586-588.

38. Lund RD, Simons DJ, Retinal transplants: structural and functional interrelations with host brain. In A Bjorklund, U Stenvi (Eds.), Neural grafting in the mammalian CNS. Amsterdam: Elsevier, 1985, pp. 345354.

39. Marrero-Rodriguez A, Yeh HH, del Cerro M. Selective transplantation of enriched cell populations derived from immature rat retina. IIIrd International Symposium on Neural Transplantation, Restor Neurol Neurosci 1989; Suppl: 30.

40. McLoon LK, McLoon SC, Chang FF, Steedman JG, Lund RD. Visual system transplanted to the brain of rats. In A Bjorklund, U Stenivi (Eds.),Neural grafting in the mammalian CNS. Amsterdam: Elsevier, 1985, pp. 267-283.

41. McLoon SC, McLoon LK. Transplantation of the developing mammalian visual system. In JR Sladek Jr, DM Gash (Eds.), Neural transplants, development and function. New York: Plenum Press, 1984, pp. 99-124. 
42. McLoon SC, McLoon LK. Factors mediating the pattern of axonal projections from retinal transplants into the host brain. In A Bjorklund, U Stenivi (Eds.), Neural grafting in the mammalian CNS. Amsterdam: Elsevier, 1985, pp. 355-362.

43. McLoon SC, McLoon LK. Multiple trophic influences which act on developing retinal ganglion cells: studies of retinal transplants. Prog Brain Res 1988; 78:377-381.

44. Mullen RJ, LaVail MM. Inherited retinal dystrophy: primary defect in the pigment epithelium determined with experimental rat chimeras. Science 1976; 192:799. 801.

45. Ninomiya S. [Morphological changes of embryonic retina and tectum transplanted into the anterior eye chamber of adult rats]. Nippon Ganka Gakkai Zesshi 1989; 93:475-483 (English abstract).

46. Royo PE, Quay WB. Retinal transplantation from fetal to maternal mammalian eye. Growth 1959; 23:313-336.

47. Seiler M, Aramant R, Adolf AR. Transplantation of cryopreserved embryonic retina into adult rat retina. IIIrd International Symposium on Neural Transplantation, Restor Neurol Neurosci 1989; Suppl: 30.

48. Seiler M, Aramant R, Ehinger B, Adolph AR. Rabbit retina transplants to adult rabbit retina. Soc. Neurosci Abstr 1988; 14: 1276.

49. Seiler M, Turner JE. The activities of host and graft glial cells following retinal transplantation into the adult rat eye: developmental expression of glial markers. Devel Brain Res 1988; 43:111-122.

50. Sheedlo HJ, Li L, Turner JE. Functional and structural characteristics of photoreceptor cells rescued in RPEcell grafted retinas of RCS dystrophic rats. Exp Eye Res 1989; 48:841-854.

51. Sheedlo HJ, Li J, Turner JE. Photoreceptor cell rescue at early and late RPE-cell transplantation periods during retinal disease in RCS dystrophic rats. J Neur Transplant 1991; 2:55-63.
52. Silverman MS, Hughes SE. Transplantation of human photoreceptors to light damaged retina. Soc Neurosci Abstr 1988; 14:1278.

53. Silverman MS, Hughes SE. Light dependent activation of light damaged retina by transplanted photoreceptors. ARVO Abstracts, Invest Ophthalmol Vis Sci 1989; 30 (Suppl):208.

54. Silverman MS, Hughes SE. Transplantation of photoreceptors to light-damaged retina. Invest Ophthalmol Vis Sci 1989; 30:1684-1690.

55. Silverman MS, Hughes SE. Photoreceptor rescue in the RCS rat without pigment epithelium transplantation. Current Eye Res 1990; 9:183-191.

56. Turner JE, Blair JR. Newborn rat retinal cells transplanted into a retinal lesion site in adult host eyes. Devel Brain Res 1986; 26:91-104.

57. Turner JE, Blair JR, Chappel ET. Peripheral nerve implantation into a penetrating lesion of the eye: stimulation of the damaged retina. Brain Res 1986; 376:246-254.

58. Turner JE, Blair JR, Chappel ET. Peripheral nerve implant effects on survival of retinal ganglion layer cells after axotomy initiated by a penetrating lesion. Brain Res 1987; 419:46-54.

59. Turner JE, Blair JR, Chappel TE. Successful grafting of embryonic rat retinal tissue into the lesion of an adult host retina. Ann NY Acad Sci 1987; 495:797-799.

60. Turner JE, Blair JR, Seiler M, Aramant R, Laedtke TW, Chappell ET, Clarkson L. Retinal transplants and optic nerve bridges: possible strategies for visual recovery as a result of trauma or disease. Int Rev Neurobiol 1988; 29:281-308.

61. Turner JE, Seiler M, Aramant R, Blair JR. Embryonic retinal grafts transplanted into the lesioned adult rat retina. Prog Brain Res 1988; 78:131-139. 

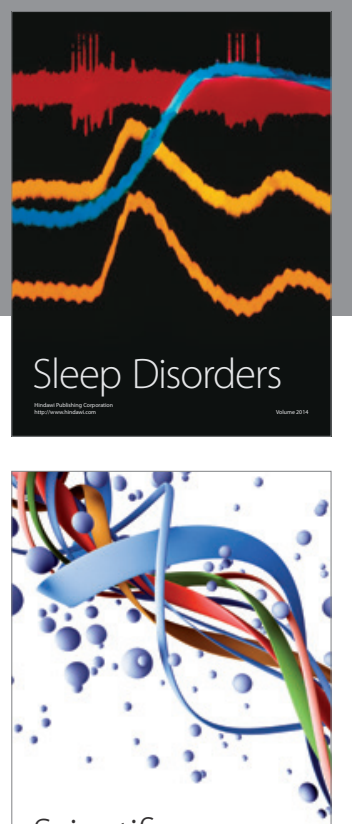

Scientifica
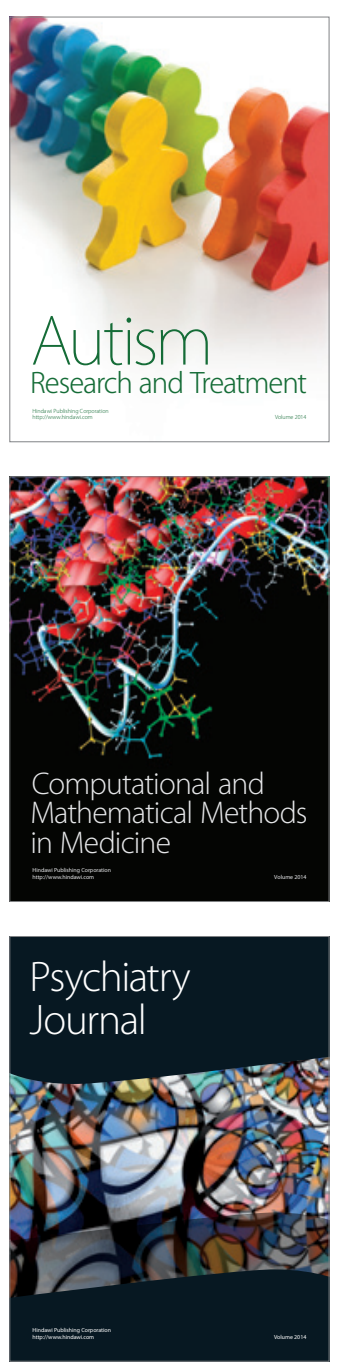
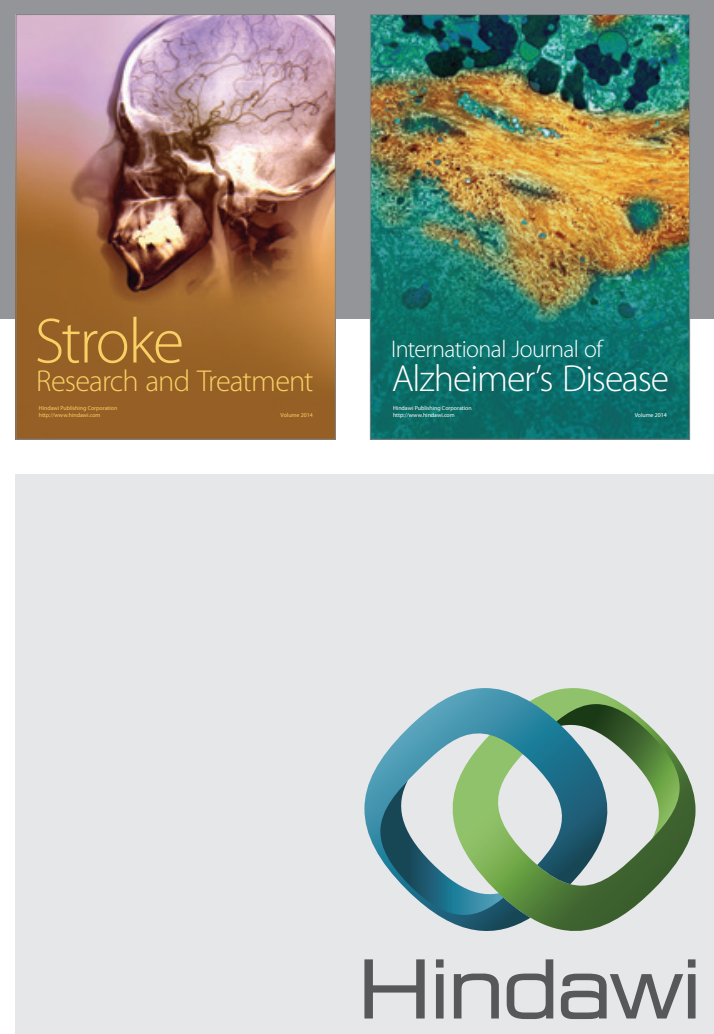

Submit your manuscripts at

http://www.hindawi.com
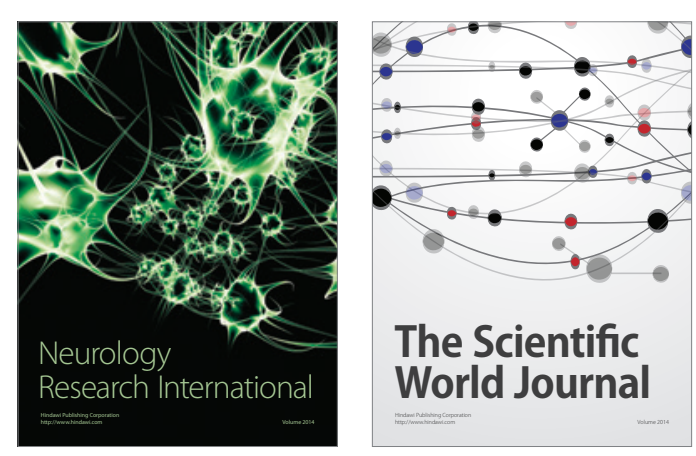

The Scientific World Journal

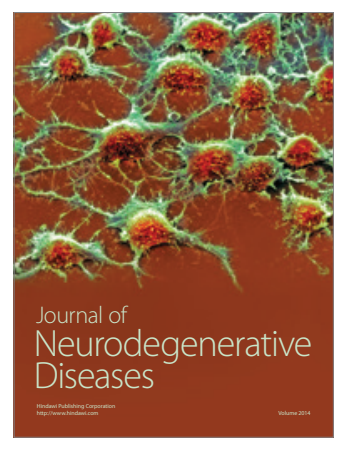

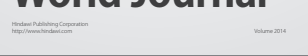

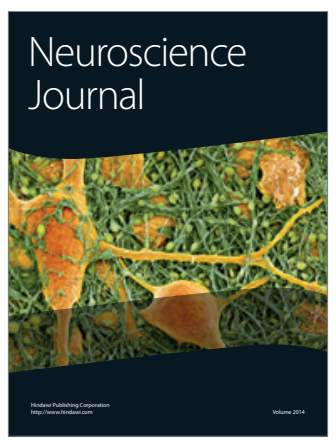

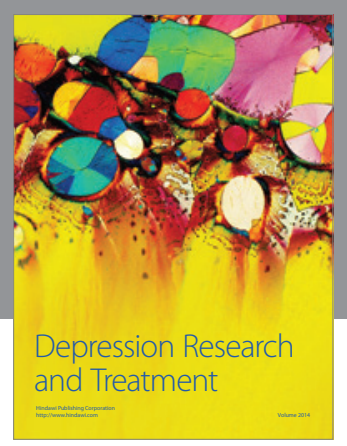
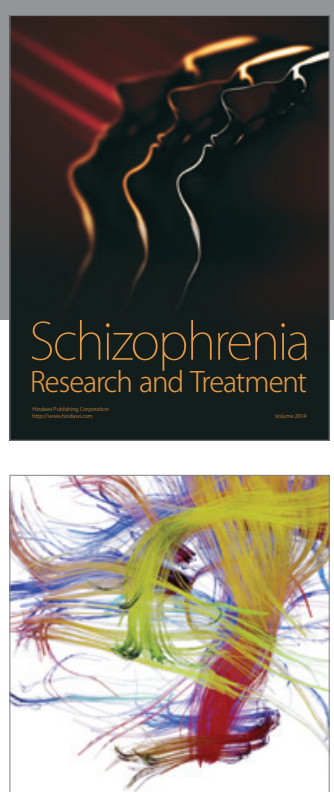

Brain Science

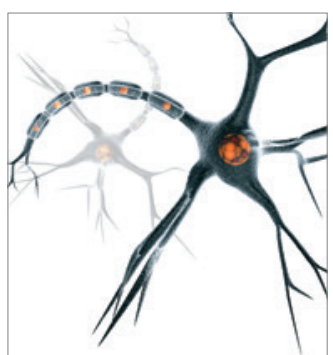

Neural Plasticity
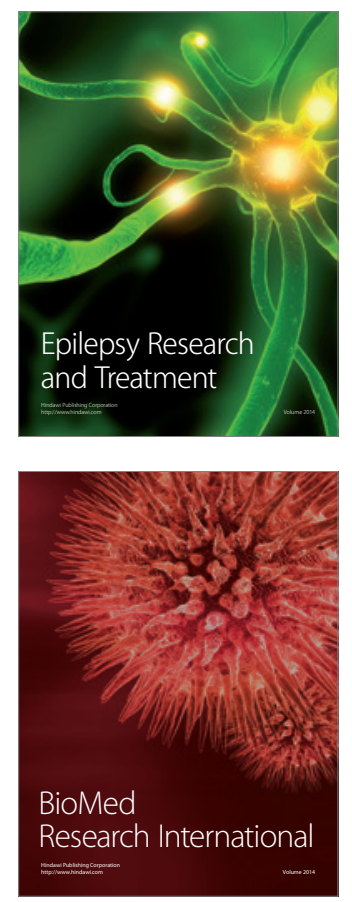

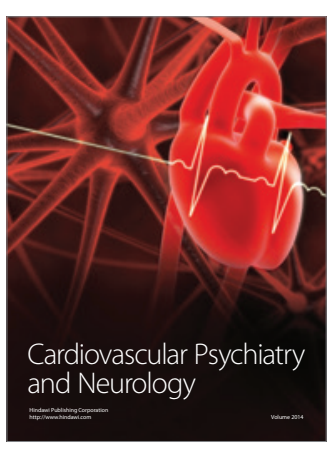

Parkinson's

Disease
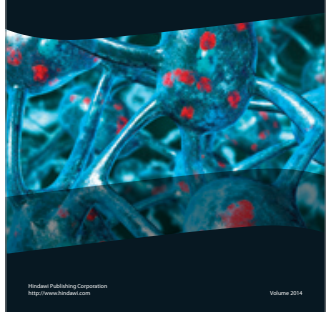